\title{
PENGUKURAN PEMAHAMAN MAHASISWA PADA PEMBELAJARAN PRONUNCIATION SECARA DARING DAN LURING
}

\author{
Riski Sulistiyaningsih, Nur Fadhilah, Tri Pudji Wahjuningsih STMIK \\ Widya Pratama Pekalongan \\ Jalan Patriot No. 25 Pekalongan \\ riskisul19@gmail.com,_ella_sef@yahoo.com, tripujiwahjuningsih@gmail.com
}

\begin{abstract}
ABSTRAK
Penelitian ini bertujuan untuk menggambarkan secara terperinci tingkat pemahaman mahasiswa terhadap materi pronunciation pada bahasa Inggris yang disampaikan secara daring dan secara luring. Populasi penelitian ini adalah mahasiswa semester 2 prodi Pendidikan Bahasa Inggris pada salah satu universitas swasta di kota Pekalongan yang mengikuti kelas mata kuliah pronunciation secara luring (tatap muka) yaitu mahasiswa pada tahun akademik 2018/2019 sejumlah 31 orang dan mahasiswa yang mengikuti kelas mata kuliah pronunciation secara daring yaitu mahasiswa pada tahun akademik 2019/2020 sejumlah 31 orang, dengan jumlah total populasi sebesar 62 mahasiswa. Metode yang digunakan adalah metode deskriptif yang menggambarkan tingkat pemahaman mahasiswa pada pembelajaran pronunciation yang dilakukan secara daring dan luring (tatap muka) secara terperinci. Hasil penelitiannya menunjukkan bahwa mahasiswa lebih memahami materi pronunciation dan lebih mampu mempraktekkan pelafalan dengan baik jika proses pembelajaran dilakukan melalui tatap muka (luring) dan jika proses pembelajaran dilakukan secara daring maka metode dan teknik penyampaian materi sebaiknya disesuaikan dengan kebutuhan mahasiswa. Hal ini juga dibuktikan dengan nilai rata-rata mahasiswa yang mengikuti perkuliahan secara luring lebih baik yaitu 76,32; sedangkan nilai rata-rata mahasiswa yang mengikuti pembelajaran secara daring adalah 69,84 .
\end{abstract}

Keywords : pronunciation, pembelajaran daring, pembelajaran luring

\section{PENDAHULUAN}

Pronunciation merupakan hal yang krusial yang harus dikuasai oleh seseorang dalam mempelajari bahasa asing. Jika seseorang tersebut tidak mempu melafalkan kosakata dalam bahasa asing secara tepat, maka akan terdengar aneh, ambigu, bahkan dapat mengakibatkan kesalahpahaman bagi orang lain yang mendengarnya.

Pada umumnya di sekolah tinggi atau universitas yang memiliki jurusan bahasa asing, akan memberikan mata kuliah atau pembelajaran pronunciation. Hal ini juga berlaku pada salah satu universitas swasta di kota Pekalongan yang memiliki program studi bahasa Inggris yaitu di Universitas Pekalongan (Unikal). Di Unikal atau lebih tepatnya di prodi Pendidikan Bahasa Inggris diberikan mata kuliah English Pronunciation di semester 2 untuk mahasiswanya. Mata kuliah ini lebih merujuk pada praktek pelafalan kosakata dalam bahasa Inggris secara tepat. Proses pembelajaran yang selama ini berlangsung adalah proses pembelajaran secara tatap muka di dalam kelas dengan cara dosen memberikan materi, 
contoh pelafalan kosakata dengan tepat, tugas, dan feedback secara langsung. Namun, dengan adanya situasi pandemi seperti sekarang ini, maka proses belajar mengajar dilakukan secara daring (dalam jaringan) yang menggunakan berbagai media yaitu google meet, audio recording, maupun video.

Dari latar belakang masalah yang telah dikemukakan di atas, maka peneliti tertarik untuk meneliti pengukuran tingkat pemahaman mahasiswa pada pembelajaran pronunciation yang dilakukan secara daring dan luring (tatap muka).Penelitian ini dilakukan dengan cara mengamati pemahaman mahasiswa terhadap materi pronunciation, penguasaan pronunciation pada mahasiswa yang mengikuti perkuliahan secara daring ataupun tatap muka, sehingga dapat diketahui adakah perbedaan pemahaman materi pembelajaran yang diperoleh mahasiswa ketika materi disampaikan secara langsung melalui tatap muka dengan materi pembelajaran yang disampaikan secara daring.

\section{TINJAUAN PUSTAKA}

\subsection{Pronunciation}

Menurut Hewings (2004:3) pronunciation adalah komponen tuturan yang berasal dari individu atau seseorang ketika berujar, dimana nada naik turunnya suara digunakan untuk menyampaikan makna. Hal ini berarti bahwa komponen dalam pronunciation adalah intonasi yang digunakan untuk membuat orang lain mudah memahami apa yang disampaikan. Ur (2009:103) menyampaikan bahwa pronunciation adalah cara untuk mengucapkan bunyi dengan benar, menggunakan kata untuk mengungkapkan arti dengan tepat, atau menyususn kalimat lisan dengan tepat agar maknanya bisa diterima dan dipahami. Hal ini bermakna bahwa seseorang dapat mengekspresikan perasaan mereka dan menyampaikannya dengan menggunakan ujaran yang tepat.

Mempelajari pronunciation adalah tugas yang sangat kompleks. Proses belajar pronunciation dapat difasilitasi jika tugasnya terstruktur. Dalam proses ini, dosen dan mahasiswa terlibat dalam peran yang penting. Peran dosen adalah membantu mahasiswa mendengar dan mengeluarkan suara. Mahasiswa meniru suara yang dilafalkan oleh dosen. Jika mahasiswa tidak dapat menirukannya, maka dosen dapat memberikan tanda atau symbol tertentu untuk membuat mahasiswa memahami kekurangannya dan memperbaiki pelafalannya supaya tepat.

\subsection{Pembelajaran daring}

Wina Sanjaya

(2008:51) mengemukakan bahwa pembelajaran merupakan kegiatan yang bertujuan membelajarkan siswa. Tujuan pembelajaran adalah kemampuan (kompetensi) atau keterampilan yang diharapkan dapat dimiliki oleh siswa setelah mereka melakukan proses pembelajaran tertentu (Wina Sanjaya, 2008:86). Terdapat berbagai macam model pembelajaran yang salah satunya adalah pembelajaran daring. Pembelajaran daring merupakan pembelajaran tanpa tatap muka secara langsung antara dosen dan mahasiswa, tetapi dilakukan melalui online. Pembelajaran dilakukan melalui video conference, e-learning atau distance learning.

\subsection{Pembelajaran tatap muka}

Kegiatan tatap muka adalah kegiatan pembelajaran yang berupa proses interaksi antara peserta didik, materi pembelajaran, guru, dan lingkungan (Peraturan Menteri Pendidikan Nasional Nomor 22 Tahun 2006, Glosarium butir 15). Dalam mengajar, metode yang sering kali digunakan adalah metode tatap muka di kelas. Secara umum terdapat strategi pembelajaran tatap muka yaitu strategi yang berpusat pada guru (teacher centre oriented) dan strategi yang 
berpusat pada peserta didik (student centre oriented).

\section{METODE PENELITIAN}

\subsection{Metode Penelitian}

Metode yang digunakan adalah metode deskriptif. Adapun Metode penyediaan data yang digunakan adalah metode kuesioner dan observasi.

\subsection{Metode Analisis Data}

Data dalam penelitian ini adalah berupa skor (nilai) mahasiswa. Rumus statistik sederhana yang akan digunakan adalah rata-rata dan persentase. Rata-rata digunakan untuk mengetahui nilai rata-rata mahasiswa. Sedangkan persentase digunakan untuk mengetahui informasi yang lebih spesifik terkait dengan hasil kuesioner yang telah diperoleh dari mahasiswa terhadap pemahaman materi pronunciation yang diberikan baik secara daring maupun luring (tatap muka).

\section{HASIL PENELITIAN}

\subsection{Deskripsi temuan data}

Terdapat dua kelompok mahasiswa dengan tahun akademik yang berbeda yaitu mahasiswa semester 2 PBI pada tahun akademik 2018/2019 sejumlah 31 orang yang mengikuti proses perkuliahan secara tatap muka dan mahasiswa yang mengikuti kelas mata kuliah pronunciation secara daring yaitu mahasiswa semester 2 PBI pada tahun akademik 2019/2020 sejumlah 31 orang, dengan jumlah total populasi sebesar 62 mahasiswa. Penelitian hanya dilakukan pada mata kuliah Pronunciation yang dijalani oleh mahasiswa semester 2 karena mata kuliah ini merupakan mata kuliah yang dilakukan dengan memberikan banyak praktek pelafalan kosakata dalam Bahasa Inggris secara langsung yang harus dilakukan oleh mahasiswa. Mahasiswa harus mampu mengucapkan atau melafalkan kosakata dalam bahasa Inggris secara benar sesuai dengan pelafalan dengan model British dan American. Dalam mata kuliah Pronunciation ini mahasiswa diajarkan cara membaca atau melafalkan simbol fonetik pada Bahasa Inggris. Maka dapat dikatakan bahwa mata kuliah Pronunciation ini menggabungkan media tulis berupa bentuk symbol fonetik secara tertulis dan media lisan berupa contoh bunyi simbol fonetik tersebut secara lisan.

\subsection{Hasil Kuesioner}

Terdapat 10 pertanyaan yang diberikan pada kuesioner ini, baik itu untuk mahasiswa semester 2 tahun akademik 2018/2019 yang memperoleh pembelajaran Pronunciation secara luring (tatap muka) maupun untuk mahasiswa semester 2 tahun akademik 2019/2020 yang memperoleh pembelajaran Pronunciation secara daring. Hasil persentase pada tiap nomor pertanyaan dalam kuesioner ini dilihat berdasarkan hasil persentase terbanyak atau tertinggi yang diperoleh pada tiap nomor pertanyaannya. Adapun hasilnya adalah sebagai berikut

\subsubsection{Semester 2 Tahun akademik 2018/2019 (Luring)}

Pertanyaan nomor 1 menyatakan bahwa mahasiswa sudah dapat membaca simbol fonetik sebelum mendapatkan mata kuliah Pronunciation. Hasilnya menunjukkan bahwa sebesar $74,8 \%$ mahasiswa belum bisa membaca simbol fonetik dalam Bahasa Inggris sebelum mendapatkan pembelajaran Pronunciation.

Pertanyaan nomor 2 menyatakan bahwa mahasiswa merasa kesulitan melafalkan bunyi simbol fonetik jika contoh pelafalannya hanya diberikan melalui video atau audio recorder. Hasilnya adalah 74,2\% mahasiswa merasa kesulitan melafalkan bunyi simbol fonetik jika contoh yang diberikan hanya melalui video atau audio recorder saja. 
Pertanyaan nomor 3 menyatakan bahwa jika perkuliahan Pronunciation diadakan secara daring maka mahasiswa dapat mempraktekkan Pronunciation dengan benar setelah mengikutinya. Hasilnya menunjukkan sebanyak 58,1\% mahasiswa merasa tidak dapat mempraktekkan Pronunciation kosakata tertentu jika perkuliahan diadakan secara daring.

Pertanyaan nomor 4 menyatakan bahwa jika materi pembelajaran Pronunciation disampaikan melalui video/audio recorder maka mahasiswa tetap dapat memahami cara melafalkan simbol/bunyi fonetik. Hasilnya adalah $58,1 \%$ mahasiswa merasa tidak dapat memahami cara melafalkan simbol/bunyi fonetik jika materi disampaikan melalui video/audio recorder.

Pertanyaan nomor 5 menyatakan jika perkuliahan dilakukan secara daring maka metodenya tetap mudah diikuti. Hasilnya $58 \%$ mahasiswa menyatakan bahwa metode perkuliahan secara daring tidak mudah diikuti.

Pertanyaan nomor 6 menyatakan bahwa mahasiswa lebih memahami perbedaan bunyi pada tiap simbol fonetik melalui kuliah tatap muka. Hasilnya sebanyak 96,7\% mahasiswa lebih memahami perbedaan bunyi pada tiap simbol fonetik jika pembelajaran diadakan secara langsung melalui kuliah tatap muka.

Pertanyaan nomor 7 menyatakan bahwa mahasiswa lebih memahami materi tentang Pronunciation ketika disampaikan langsung melalui tatap muka. Hasilnya adalah $100 \%$ mahasiswa menyatakan bahwa mereka lebih memahami materi tentang Pronunciation ketika disampaikan langsung melalui tatap muka.

Pertanyaan nomor 8 menyatakan bahwa sistem penilaian kuliah Pronunciation bersifat obyektif. Terdapat $90,3 \%$ mahasiswa menyatakan bahwa sistem penilaian kuliah
Pronunciation bersifat obyektif yang artinya bahwa mahasiswa yang memperoleh nilai baik berarti dia mampu memahami materi yang disampaikan dalam perkuliahan Pronunciation tersebut.

Pertanyaan nomor 9 menyatakan bahwa penugasan yang diberikan pada mata kuliah Pronunciation terbukti membantu dalam penguasaan materi. Adapun hasil yang diperoleh menunjukkan bahwa sebanyak $100 \%$ mahasiswa menyatakan bahwa penugasan yang diberikan pada mata kuliah Pronunciation ini dapat membantu mahasiswa dalam menguasai materi.

Pertanyaan nomor 10 menyatakan bahwa jika kuliah diberikan secara daring atau kuliah diberikan melalui tatap muka secara langsung maka akan memberikan efek yang sama bagi mahasiswa dalam memahami materi Pronunciation. Sebanyak 83,9\% mahasiswa menyatakan bahwa jika pembelajaran diberikan secara daring memberikan efek yang tidak sama dengan pembelajaran yang diadakan secara tatap muka langsung terhadap mahasiswa dalam memahami materi pembelajaran Pronunciation.

Kesimpulan dari hasil kuesioner terhadap mahasiswa semester 2 tahun akademik 2018/2019 menyatakan bahwa para mahasiswa lebih memahami materi pembelajaran dan lebih mampu untuk mempraktekkan bunyi kosakata tertentu atau membaca simbol fonetik dalam Bahasa Inggris pada mata kuliah Pronunciation jika materi dan contoh pelafalan bunyi simbol fonetik disampaikan secara langsung melalui proses perkuliahan tatap muka secara langsung di dalam kelas.

\subsubsection{Semester 2 Tahun akademik 2019/2020 (Daring)}

Pertanyaan nomor 1 menyatakan bahwa mahasiswa sudah dapat membaca 
simbol fonetik sebelum mendapatkan mata kuliah Pronunciation. Hasilnya adalah 58,1\% mahasiswa menyatakan belum bisa membaca simbol fonetik dalam Bahasa Inggris sebelum mendapatkan pembelajaran Pronunciation.

Pertanyaan nomor 2 menyatakan bahwa mahasiswa merasa kesulitan melafalkan bunyi simbol fonetik jika contoh pelafalannya hanya diberikan melalui video atau audio recorder. Terdapat 58\% mahasiswa merasa kesulitan melafalkan bunyi simbol fonetik jika contoh yang diberikan hanya melalui video atau audio recorder saja.

Pertanyaan nomor 3 menyatakan bahwa mahasiswa dapat mempraktekkan Pronunciation dengan benar setelah mengikuti perkuliahan secara daring. Hasilnya 54,9\% mahasiswa merasa dapat mempraktekkan Pronunciation kosakata tertentu setelah mengikuti perkuliahan yang diadakan secara daring.

Pertanyaan nomor 4 menyatakan bahwa mahasiswa tetap dapat memahami cara melafalkan simbol/bunyi fonetik meskipun materi disampaikan melalui video/audio recorder. Hasilnya sebanyak $77,4 \%$ mahasiswa merasa dapat memahami cara melafalkan simbol/bunyi fonetik meskipun materi disampaikan melalui video/audio recorder.

Pertanyaan nomor 5 menyatakan bahwa metode perkuliahan pronunciation secara daring mudah diikuti. Terdapat $73,5 \%$ mahasiswa menyatakan bahwa metode perkuliahan Pronunciation secara daring mudah diikuti.

Pertanyaan nomor 6 menyatakan bahwa mahasiswa lebih memahami perbedaan bunyi pada tiap simbol fonetik melalui kuliah tatap muka. Hasilnya sebanyak $100 \%$ mahasiswa menyatakan lebih memahami perbedaan bunyi pada tiap simbol fonetik jika pembelajaran diadakan secara langsung melalui kuliah tatap muka.
Pertanyaan nomor 7 menyatakan bahwa mahasiswa lebih memahami materi tentang Pronunciation ketika disampaikan langsung melalui tatap muka. Hasilnya menunjukkan bahwa sebanyak $100 \%$ mahasiswa menyatakan bahwa mereka lebih memahami materi tentang Pronunciation ketika disampaikan langsung melalui tatap muka.

Pertanyaan nomor 8 menyatakan bahwa sistem penilaian kuliah Pronunciation bersifat obyektif. Terdapat $93,6 \%$ mahasiswa menyatakan bahwa sistem penilaian kuliah Pronunciation bersifat obyektif yang artinya bahwa mahasiswa yang memperoleh nilai baik berarti dia mampu memahami materi yang disampaikan dalam perkuliahan Pronunciation tersebut.

Pertanyaan nomor 9 menyatakan bahwa penugasan yang diberikan pada mata kuliah Pronunciation terbukti membantu dalam penguasaan materi. Totalnya terdapat 96,8\% mahasiswa yang menyatakan bahwa penugasan yang diberikan pada mata kuliah Pronunciation ini dapat membantu mahasiswa dalam menguasai materi.

Pertanyaan nomor 10 menyatakan bahwa kuliah melalui daring dan kuliah secara tatap muka langsung memberikan efek yang sama bagi mahasiswa dalam memahami materi Pronunciation. Total sebanyak 58,1\% mahasiswa menyatakan bahwa pembelajaran Pronunciation yang diberikan secara daring memberikan efek yang tidak sama dengan pembelajaran Pronunciation yang diadakan secara tatap muka langsung terhadap mahasiswa dalam memahami materi.

Kesimpulan yang didapatkan dari hasil kuesioner pada mahasiswa semester 2 tahun akademik 2019/2020 yang mendapatkan materi pembelajaran Pronunciation secara daring menyatakan bahwa mahasiswa tetap dapat memahami materi pembelajaran jika metode dan teknik 
yang digunakan oleh pengampu mata kuliah sesuai dengan kebutuhan mereka, karena dari hasil kuesioner tersebut juga menunjukkan bahwa para mahasiswa merasa lebih memahami materi Pronunciation jika pembelajaran disampaikan secara langsung melalui tatap muka.

\subsection{Hasil Nilai Rata-Rata Ujian}

Nilai yang dianalisa pada penelitian ini diambil dari hasil nilai ujian tengah semester (UTS) dan nilai ujian akhir semester (UAS) yang telah diperoleh mahasiswa selama mengikuti pembelajaran Pronunciation.

Adapun ujian baik itu UTS maupun UAS dilakukan secara lisan sehingga tidak ada ujian tertulis. Soal ujian diberikan secara tertulis namun mahasiswa harus menjawab soal tersebut secara lisan.

Perbedaan pelaksanaan ujian secara luring (tatap muka) dan secara daring adalah dalam tahun akademik 2018/2019 dimana pembelajaran diadakan secara luring (tatap muka), mahasiswa menjawab soal secara langsung (secara lisan) dan membuat video ketika melafalkan kosakata dan membaca simbol fonetik. Sedangkan dalam tahun akademik 2019/2020 ujian diadakan secara daring dengan cara mahasiswa menjawab soal secara lisan melalui media google meet dan membuat video ketika melafalkan kosakata tertentu dan membaca simbol fonetik.

Adapun hasil (nilai) yang diperoleh mahasiswa adalah seperti dibawah ini

\subsubsection{Semester 2 Tahun akademik 2018/2019 (Luring)}

Nilai rata-rata Ujian Tengah Semester (UTS) yang diperoleh 31 mahasiswa adalah 73,8065 . Hasil tersebut diperoleh dari perhitungan di bawah ini :

$$
\begin{aligned}
& X=\frac{\sum x}{N} \\
& X=\frac{2288}{31}=73,8065
\end{aligned}
$$

Keterangan :

$\mathrm{X}=$ nilai rata-rata UTS

$\sum x=$ jumlah total nilai UTS

$\mathrm{N}=$ jumlah mahasiswa

Nilai rata-rata Ujian Akhir Semester (UAS) yang diperoleh 31 mahasiswa adalah 76,3225 . Adapun perhitungan nilainya adalah

$\mathrm{y}=\frac{\sum y}{N}$

$y=\frac{2366}{31}=76,3225$

Keterangan :

$\mathrm{y} \quad=$ nilai rata-rata UAS

$\sum \mathrm{y}=$ jumlah total nilai UAS

$\mathrm{N}=$ jumlah mahasiswa

\subsubsection{Semester 2 Tahun akademik 2019/2020 (Daring)}

Nilai rata-rata Ujian Tengah Semester (UTS) yang diperoleh 31 mahasiswa adalah 67,3871. Hasil tersebut diperoleh dari

$\mathrm{X}=\frac{\sum x}{N}$

$X=\frac{2089}{31}=67,3871$

Keterangan :

$\mathrm{X}=$ nilai rata-rata UTS

$\sum x=$ jumlah total nilai UTS

$\mathrm{N} \quad=$ jumlah mahasiswa

Nilai rata-rata Ujian Akhir Semester (UAS) yang diperoleh 31 mahasiswa adalah 69,8387 . Adapun perhitungan nilainya adalah

$\mathrm{y}=\frac{\sum y}{N}$ 
$y=\frac{2165}{31}=69,8387$

Keterangan :

$\mathrm{y} \quad=$ nilai rata-rata UAS

$\sum \mathrm{y}=$ jumlah total nilai UAS

$\mathrm{N} \quad=$ jumlah mahasiswa

Dari hasil perhitungan nilai rata-rata baik itu nilai UTS dan UAS yang diperoleh mahasiswa menunjukkan bahwa mahasiswa semester 2 pada tahun akademik 2018/2019 yang mendapatkan pembelajaran Pronunciation secara luring (tatap muka) lebih baik atau lebih tinggi daripada nilai ratarata yang diperoleh mahasiswa semester 2 tahun akademik 2019/2020 yang mendapatkan pembelajaran Pronunciation secara daring (online).

\section{KESIMPULAN}

Dari hasil yang didapatkan terhadap pemahaman mahasiswa pada pembelajaran Pronunciation secara daring dan luring (tatap muka) maka peneliti dapat menyimpulkan bahwa:

1. Mahasiswa lebih memahami materi pelajaran Pronunciation yang disampaikan secara langsung melalui luring (tatap muka) karena contoh suara yang diberikan oleh pengajar lebih jelas.

2. Mahasiswa lebih mampu mempraktekkan pelafalan dengan baik jika diberikan contoh secara langsung melalui luring (tatap muka) karena mahasiswa dapat melihat secara langsung penempatan organ wicara pemberi contoh lafal (dalam hal ini adalah pengajar)

3. Hasil ujian mahasiswa menunjukkan bahwa nilai rata-rata mahasiswa yang mengikuti proses pembelajaran secara luring (tatap muka) lebih tinggi daripada nilai rata-rata mahasiswa yang mengikuti proses pembelajaran secara daring (online).

\section{DAFTAR PUSTAKA}

HD. Brown. 2004. Language Assessment : Principle and Classroom Practices. New York: Pearson Education

HD. Brown. 2001. Teaching by Principle: An Interactive Approach to Language Pedagogy. New York: Pearson Education

Hewings, Martin. 2004. Pronunciation Practice Activities: A Resource Book for

Teaching Engllish Pronunciation. Cambridge: Cambridge University Press.

Nunan, David. 2011. Teaching English to Young Learners. Anaheim: Anaheim Univesity Press.

Ur, Penny. 2009 A Course in Language Teaching : Practice and Theory. Cambridge: Cambridge University Press.

Sanjaya, Wina. 2008. Strategi Pembelajaran Berorientasi Standar Proses Pendidikan. Jakarta: Kencana Prenada Group.

Sudaryanto. 1993. Metode dan Aneka Teknik Analisis Bahasa. Yogyakarta: DutaWacana University Press 